\title{
MULTIDISCIPLINARY RESEARCH ON SHOREA JAVANICA
}

\section{FOREWORD}

It was April 1985, under the leadership of Dr. Ir. Z. Goto, then Tropical Forest Biology Program Manager, that it was decided to launch in BIOTROP a multidisciplinary research on Shorea javanica. This followed the publication in 1984 by E.F. Torquebiau of a paper describing the traditional planting of this tree for resin production by farmers near the small town of Krui, in Lampung Province, Southern Sumatra (Man-made dipterocarp forest in Sumatra. Agroforestry Systems, 2: 103-127). A proposal was subsequently made to develop in BIOTROP different research topics around this species in order to promote it for plantation forestry. The choice of this species was justified by the important knowledge from its traditional uses and planting, while in the long term, it is hoped that the development of plantations of this species will promote the use of other dipterocarps and native trees for plantation forestry. 


\title{
I. INTRODUCTION
}

\author{
E.F. TORQUEBIAU*
}

Tropical Forest Biology Program, BIOTROP, Bogor, Indonesia

The plantations of Shorea javanica K.\&V. (Dipterocarpaceae) in the district of Krui (Lampung province, Sumatra; see Fig. 1 for situation map and main climatic data) are remarkable examples of successful land development after deforestation and shifting cultivation which was mentioned in the Indonesian forestry literature as far back as 1937 (Rappard 1937). This tree is a white Meranti which is locally found in the natural forest and tapped for its beautiful, crystalline resin, or "damar". The local name of the tree is "Damar Mata Kucing", which means "cat's eye resin".

One of the traditional cultivation systems in the area is shifting cultivation ("ladang"): rain-fed rice is grown during one or two years and then coffee, other crops, and damar trees are planted to convert the ladang into a permanent agricultural field. The damar trees close their canopies above the other crops after some years and can be tapped for resin after about 15 years and during a rotation of approximately 50 years. They constitute dense stands of 40-50 m high trees called "kebun damar" (damar gardens) which look like a natural rain forest. Seeds for planting stock were formerly obtained from the surrounding natural forest but nowadays they come from the pre-existing plantations which cover an area of approximately 1000 ha (Scholz 1983). Fruiting seasons are occasional and irregular, often several years spaces, so that the farmers manage large nurseries of seedlings which can be maintained for several years and transplanted to the plantations when needed. Transplantation of bare-rooted seedlings is easy.

Other useful trees (e.g. clove trees), are simultaneously planted in the ladang at the time of planting the damar trees, so that, although the latter largely dominate, the resulting stand is a multi-layered, mixed one, comprising of different useful plants (fruits, vegetables, medicinal plants, etc.). The whole cultivation system, from the shifting cultivation stage to the establishment of a permanent tree plantation, constitutes an efficient agroforestry system which is extensively described by Michon 1984, 1985; Michon et al 1984; and Torquebiau 1984.

The resin of Shorea javanica is traditionally used for torches, caulking boats, batik coloring, etc., and is now exported to industrial countries where there is market for uses such as food additives, cosmetics, paints, varnishes and

\footnotetext{
* Present address: ICRAF, P.O. Box 30677, Nairobi, Kenya.
} 
I. Introduction - E.F. Torquebiau

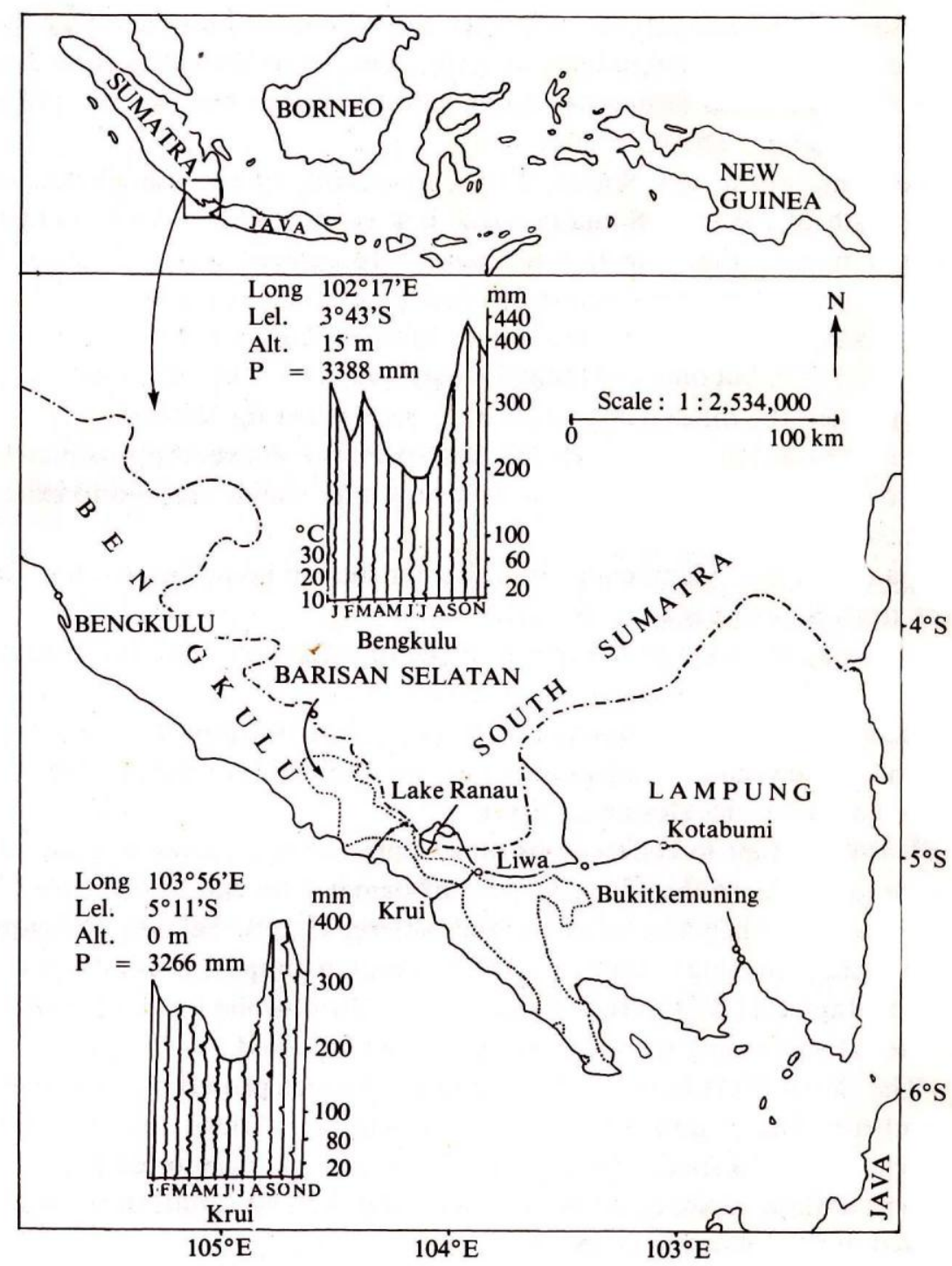

Figure 1. Situation map and main climatic data (Torquebiau 1984). 
medications. However, the resin is exported as raw material and there is no industrial unit yet for resin processing in Indonesia.

Although the only significantly large area of Damar Mata Kucing plantation in Sumatra is in the surroundings of Krui, some other localities were found in Southern Sumatra, indicating that at one time, the damar business was probably a very attractive one. These localities are:

- Bakauheni, at the very Southern tip of Sumatra, $10 \mathrm{~km}$ from Bakauheni, to the north of the trans-Sumatra road, is a small stand of fairly old, disused damar trees. Other damar trees can be recognized here and there in the landscape, and there are probably other plantations in this area.

- Sukadana, near Way Kambas nature reserve. This locality was reported by Meijer (1975), but only one [huge!] tree is now left in the village and is disused. People said the other damar trees have been felled for timber!

- Wana (Sribowhono), some $25 \mathrm{~km}$ East from the above. Approximately 1 ha stand of fairly old damar trees is present. Other stands are said to exist in the surroundings.

- Hujan Mas, near Muaraenim. Some damar trees in home gardens not far from the trans-Sumatra road were noted.

- Batu Raja, some km to the North of the town. Damar trees in home gardens can be seen from the trans-Sumatra road.

— Localities near Semangka bay and Kota Agung, mentioned in Meijer (1975), could not be visited. Some localities are probably also to be found in Southern Bengkulu Province (Rappard 1937).

It is important to collect seeds or seedlings when a survey is made of these different localities, so that the gene pool of damar trees can be diversified. Resin quality may differ between localities (and between trees!). Tapping techniques are also different according to the zone. The best tool to scrape the resin from the trees as said by Rappard (1937) is the "damar axe" of Krui, while further North in Lais, a different tool causing more damage to the trees is used.

The aim of BIOTROP's multidiciplinary research project on Shurea javanica is to gather sufficient information on the silviculture of this tree to serve as basis for proposing it as a species for plantation forestry and agroforestry. Up to now, only some of these topics could be dealt with and the first results of the studies are presented in the following chapters.

A sub-project on tissue culture and water culture is also going on, but has not produced any significant result yet. Aseptic germination of embryo has been successfully achieved and will be used as basis for new vegetative propagation experiments. Data and material gathering in the field were conducted in the surroundings of Krui during field trips attended by different staff members from 
BIOTROP in June, September and October 1985 (ripe seeds could be collected then!), and February 1986.

Although much research work is still to be done, it is thought that there is sufficient knowledge on the silvicultural management of this species to warrant the establishment of experimental plantations now. Executive proposals have been submitted to the Directorate of Reforestation and Land Rehabilitation (RRL) and to P.T. Kutai Timber Indonesia with the hope that such trial plantations could be started as soon as possible, with the scientific collaboration of BIOTROP. However, these proposals have not received any answer so far.

\section{REFERENCES}

MEUER, W. 1975. Indonesian forests and land-use planning. Thomas Hunt Morgan School of Biological Sciences, Univ. of Kentucky, Lexington, Kentucky 40506/Missouri botanical garden. Mimeogr. 113 pp.

MICHON, G. 1984. Prospects for the use of agroforestry systems in regional forest management: examples from Indonesia. In: BIOTROP Symposium on forest regeneration in South East Asia. May 1984, BIOTROP, Bogor, Indonesia. BIOTROP Special Publication No. 25.

MICHON, G. 1985. De Phomme de la foret au paysan de Tarbre: agroforesteries indonesiennes. Thesis, University of Montpellier, France, 273 pp + Figs.

MICHON, G., F. MARY, J.M. BOMPARD \& P. LOMBION, 1984. Traditional agroforestry in Indonesia. LIPI, Jakarta, Mimeogr.

RAPPARD, F.W. 1937. De damar van Bengkoelen. Tectona, Dl. XXX, pp. 697-915.

SCHOLZ, U. 1983. The natural regions of Sumatra and their agricultural production pattern. Vol. 1, Text: CRIFC, Bogor, Indonesia, Vol. 2, maps: SARIF, Padang, Indonesia.

TORQUEBIAU, E.F. 1984. Man-made dipterocarp forest in Sumatra. Agroforestry systems, 2: 103-127. 